\title{
THE GOLD MINES OF COSTA RICA
}

\author{
Milton Franklin Reitz \\ Transcrito por: \\ Siegfried Kussmaul
}

\section{Escuela Centroamericana de Geología, Universidad de Costa Rica}

\author{
Documento original tomado de: The Engineering and Mining Journal; \\ August 16, 1902; págs. 210-213
}

Like the mines of every other part of the world, something have been said and written of those in this republic. All connected with the mining industry know the nature and effect of such writings. It is a well-known fact that the press throughout the States have given space to reviews of this sort relative to all known mining districts, the authenticity of which has not always been without question. This articles in many instances have been produced by special reporters, who have spent limited time in their preparation, with the prime purpose of obtaining readable matter, and with the result that facts have been sacrificed to give due credit to the legends and traditions met with in all mining communities.

The object of this article is to give a correct idea of the conservative possibilities, if not probabilities, of the mining industry in Costa Rica. The writer has spent two years immediately connected with the mines of the country and has personally visited the more important properties here mentioned. Physical conditions notes are given from personal knowledge, and are corroborated by reports made at various times by eminent engineers. Statistical facts observed are taken from original mint returns, assay certificates, and bills of sale now in the file of the owners of the mines. As there is probably no better way of judging the future than by the past, I have thought it of interest to give some history, especially with reference to the mines of the Aguacate Mountain, for which I am indebted to Don Francisco María Yglesias, who, with his father before him, have been associated with these properties for more than eighty years. It was the gold of Monte Aguacate which infused the first symptoms of vitality into Costa Rican commerce. 


\section{COSTA RICA}

The name, meaning "rich coast," was given to the country by the first Spanish explorers in 1512 , when they were attracted by the many golden images worn by the native Indians. Many of these gold idols, dug from old burying grounds, are found in the collections made by the pioneers. The collection at the National Museum is valued at about $\$ 50,000$. Events subsequent to those early times show the name is an appropriate one.

This republic has an area of 34,000 square miles, and a population, according to the census of 1901 , was 311,444 . The ports of entry-Puerto Limon, on the Atlantic, and Puntarenas, on the Pacific, lie on the tenth parallel, which crosses the higher developed section, the central part of the republic. These ports have excellent landing and shipping facilities, and are both connected with the interior by railway.

The laws of the country governing mining are liberal and ample. Mining machinery and supplies are admitted free of duty, and full protection is accorded the business. Many of the leading business men of the republic are financially interested in the mines. The attitude of the government has long been especially friendly, and the present administration hopes to see the mining business develop into a chief industry. The peaceful character of the people and the stability of the government are facts worthy of particular mention in this connection.

\section{ECONOMINC CONDITIONS AFFECTING MINING}

\section{Climate}

The climate in all localities where mines are now being worked and in all places where work is contemplated is healthful and pleasant. The general elevation of the mines is about 1,800 feet. Observations taken at this elevation at the Aguacate mines indicate the average temperature at 72 degrees Fahrenheit. The temperature varies but little during all the year.

\section{Water}

This important element is well provided, and the supply of pure water is sufficient for all purposes. The mountain streams afford ample power and are numerous in the mining districts, so that immediate or transmissible power is available at moderate expense.

\section{Timber}

The native woods are well adapted to mining purposes and abound in sufficient quantity in most localities to supply this demand for many years. The timber requirements can in most of the mines be reduced to less than past consumption by employing modern methods. Cheap power and labor being available; good lumber is produced at moderate cost.

\section{Labor}

The native labor is good, cheap and steady. The miners are hard-working and intelligent. The maximum price paid to drill-men in 3 colonies, or $\$ 1.35$ gold per day, and ordinary labor is secured at half the price.

As a summary of these facts it is conservative to say that all economic conditions are favourable to profitable operations.

\section{GEOLOGY AND MINERALOGY}

To treat this subject briefly, suffice it to say that the following conditions will apply with little variation to all of the localities mentioned.

The country rock is of igneous origin ; diorite and the porphyries are the more common. Large black boulders conspicuously mark many localities. It was due to this fact that Los Quemados (which means "the burned"), a village in the interior, was so named. The ores bearing the precious metals usually occur in fissure veins, and the gangue consists principally of quartz, clay tale, and 
porphyry. The values are largely held by crystalline quartz, which occurs in all its varieties, from the pure white and barren to the highly mineralized, carrying sulphides of the base metals in varying proportions and in rarer cases manganese, arsenic and antimony. Ores presenting highly refractory features are rare. The remaining gangue often carries gold which has been freed from the quartz by aqueous agencies, to which the oxidation of the base metals and the crumbling of the quartz was probably due. The percentage of silver values in the auriferous ores I have examined is comparatively small, but, it is said, there are some rich silver ores.

\section{HISTORY}

Lost and perilous expeditions, intrigues, persecutions and other causes, especially the marine disaster suffered by the Governor of Costa Rica, Juan Vazquez de Coronado, occasioned much delay in the development of the first mineral discoveries. This was retarded also by frequent invasions by the Talamancas and other Indian tribes. During two centuries prior to 1815 , but four mineral denouncements are of record, and but two of these are located.

The first discovery affecting the principal mines known today was made in the district of the Aguacate Mountain (then called El Torroto) by the Spanish Bishop Garcia, bishop of Costa Rica and Nicaragua, while crossing the mountain over the old trail which connected Cartago, the destiny of the bishop on this journey, with other important provinces within his dominion. The principal residence of the bishop was then in Nicaragua, and a visit from him to Costa Rica was a notable event. In this particular instance more than thirty years had elapsed since the visit of his predecessor, Bishop Tristan, hence, in order to show their appreciation of the event, the Costaricans sent a delegation of prominent citizens to accompany him from Esparta to Cartago. On their way through the Aguacate mountains the bishop, who had some knowledge of ores, observed the outcropping of a vein over which they passed, and suggested the probability of gold and silver veins existing in the locality. This discovery was made on the main ledge of the miner, afterwards denounced as the Sacra Familia. The place is still marked by a surface-working, made in the discovery days. A Spanish gentlemen, Don Santos Lombardo, of Cartago, a member of the delegation, took some samples to Cartago, had them assayed and found them to be rich in gold. Returning in company with two friends, of whom was Don Rafael Gallegos, second president of Cost Rica, they denounced the mine under the name Sacra Familia (Holy Family). These first and the many subsequent discoveries caused much excitement in Costa Rica and prospecting was actively entered into.

\section{GOLD MINING ZONE}

The gold mining zone of Costa Rica lies on the Pacific slope, and comprises three different districts, viz.: The mines of the Aguacate Mountain, Monte de Oro District, and the Abangares District, the locations of which may be seen on the accompanying map.

\section{The Mines of the Aguacate District}

The position, past importance and promised future of these extensive properties suggest them for first mention. This district consists of five distinct mines or groups, viz.: The Aguacate mines, the Sacra Familia, Los Castros, Quebrada Honde and El Porvenir. They are situated in the mining district of the Aguacate Mountain, in the Province of Alajuela. The Mountain is in latitude $10^{\circ} 12^{\prime} 30^{\prime \prime}$ North, and in longitude $84^{\circ} 28^{\prime} 30^{\prime \prime}$ West of Greenwich. The Pacific Railway, now being completed to connect the capital (San Jose) with the Pacific Coast, passes within 2 miles of the mines, at the Rio Concepcion. The national cart road, connecting these points, passes the entrance to the mines at the post office Desmonte, which is about 30 miles from the Pacific port and 35 miles from San Jose. 


\section{The Main Lode}

According to a report made by an eminent engineer of San Francisco, "the vein is an exceedingly powerful one and possesses all of the characteristics of great strength and permanency. It is undoubtedly a true fissure vein. The width is from 15 to 150 feet (Nota: para transformar los pies en metros se multiplica por 0,305 , o sea, el ancho de las vetas varía entre 4,57 m y 45,72 m). Very few of the workings show both walls, although some cross-cuts are in vein matter from the foot-wall, a distance of from 25 to 30 feet. At one point in the San Rafael level, a cross-cut near the bonanza El Balsa shows the foot-wall at 8 feet, while at a lower tunnel a cut shows it to be 40 feet wide. On the national cart road a cutting exhibits a width of 150 feet. There are two parallel veins in what is known as the Oreamunos portion of the lode, one called Veta Colorado, and the other Veta Blanco, the former being next to the foot-wall and the latter towards the hanging wall. These are considered separate and distinct veins, but are unquestionably component parts of the lode. In the works of the tunnel driven, many feeders have been encountered which unite with the main lode. All indicates that this is the mother lode of the district.

"The ore varies in value, according to the locality in which it occurs. In the bonanzas it ranges from $\$ 75$ to $\$ 5,000$ per ton (Nota: para transformar los valores \$/ton en onzas troy/tonelada métrica se multiplica con el factor 0,053 ). In order to ascertain the value of the lode large samples of from 100 to 300 pounds each were carefully taken, reduced and assayed in duplicate, giving an average of $\$ 25,82 . "$

\section{La Minita}

This is a separate and strong vein. It was discovered and denounced in 1832. Considerable wealth was taken from the surface ores of this vein through the crude methods employed in the early times. This vein joins the main lode in the Los Castros property. - The assays made from the vein indicate values of $\$ 25$ to $\$ 30$ per ton.

\section{San Miguel}

This was another early discovery denounced in 1826 , and was profitably worked until after 1862 . Assays made from these ores run from $\$ 15$ to $\$ 70$ per ton $(0,8-3,7 \mathrm{oz} / \mathrm{t})$.

Of the thirteen bonanzas discovered in this immediate district, five were found in the Aguacate mines: Guapinol, El Balsa, La Cigueña, El Fuego and Don Eusebio.

\section{Guapinol}

This was one of the early discoveries, made in 1823. A native while resting in the shade of a Guapinol tree notices the peculiar appearance of the outcrop. He showed it to a man named Oreamunos, who panned it and found it rich in gold. The discoverer was dismissed with a small present, and Oreamunos with his two brothers denounces the property, calling it "La Mina del Pilar", after the holy virgin Pilar, the patroness of Zaragoagoza in Spain, although it has always borne the popular name Los Oremunos. It is estimated by well-informed authorities that the Oreamunos family took from this bonanza the sum of $\$ 1,000,000$.

\section{El Balsa}

This early discovery, which proved to be rich, was denounced as the Mina de San Rafael on the Oreamunos lode. In the year 1825 a lessee made a handsome fortune by treating the ore in an arrastra constructed on the Rio Grande, ten miles distant, to which point the ore was transported in ox carts. It was at these works that he, with the permission of the government, made the 
first Costa Rican gold coin. The assay office of the Swiss-American Bank of San Francisco, Cal., certified to assays made of ores from this bonanza of values ranging from $\$ 600$ to $\$ 4,000$.

\section{La Cigueña}

This superficial work yielded as much ore as El Balsa. The last work done there was in 1875 . The sum of $\$ 21,000$ is said to have been realized from 11 feet of ore taken from this place. The ore was treated at a place called La Union, on the Rio del Quebrada Honde, by an arrastra and a stamp mill of primitive pattern, the ruins of which may yet be seen. From the poorest kind of amalgamation they realized $\$ 84$ per ton. That these ores were rich is indicated by tests I made from what remains of old tailings dumps, which show the presence of free gold and amalgam, and values from $\$ 35$ to $\$ 80$ per ton.

\section{El Fuego}

This bonanza was discovered between the Guapinol and La Cigueña and like them was but a surface working. The proposition of draining this work was at the time of abandonment considered too great an undertaken. Authorities familiar with this mine estimated the ore then in sight to be at least 1,000 tons and valued at $\$ 300,000$. One shipment of 53 tons, made by the Aguacate company to the Royal Saxony Smelting Works, near Freiburg, Germany, in 1874, was bought on the basis of $\$ 181.27$ gold and $\$ 21.03$ silver per ton, a total value of $\$ 202.30$ per ton.

\section{Don Eusebio}

This bonanza is a part of the San Rafael property. It was discovered while drifting a tunnel to reach El Balsa. A large quantity of rich ore was mined here. I have not ascertained the value of its production. Several drifts were made in this working which are of value, as they show the continuity of some important veins of the locality.

Quite a number of shipments were made by the company in 1893 and 1894 form these various mines to London. The lots shipped ranged from half a ton to 30 tons. The lowest price received was $£ 196$ s., or $\$ 95$, per ton for a lot of 30 tons. One lot shipped in March, 1894, was bought at $£ 1,900$, or $\$ 9,500$ per ton, ten times the value of lowest price.

These were the last shipments made, and there has been no work of production since that time. The total output of the Aguacate mines has been estimated to exceed $\$ 5,500.000$. That this is conservative is proved by the marked influence which the opening of these mines had upon the general industry of the country. Until that time the country was exceedingly poor and commerce hardly existed. The circulation of these money, however, facilitated the importation of foreign manufactures necessary to develop the agricultural and other resources of the country.

\section{Sacra Familia Mines}

The scene of the first discovery in the Aguacate District, as before noted, was on the main lode of this important group, which is situated north and west of and adjoining the Aguacate properties. Numerous workings of a superficial nature are yet discernable where the lode has been attacked. No work of extent has been done in recent years. The last productive operations as far as I can learn were in 1884. For several years previous to this time a to-stamp mill was operated during the wet season. Five tons was the maximum daily capacity. The ores milled were taken from workings known as Cardinilla, Potrero Alto and Sobre Cañon de San Francisco, and were hauled to the mill by ox-cart. But a small percentage of the value was recovered in this mill, perhaps 
wholly due to improper management. I assayed some samples last november, taken from the old tailings dump, which gave values from $\$ 12$ to $\$ 33$ per ton gold. Crude and wasteful as were these operations, it is stated by a good authority that the saving was so great at times that it was considered necessary to clean the plates two o three times a day. Considering the quantity treated, such conditions are only conceivable when very rich ore is supplied.

At another point of the Rio Quebrada Honda are the ruins of an arrastra and mill of ancient make. The date of operations here I have not learned. Some of these old remnants are interesting. The wooden parts have entirely decayed and washed away. An old shaft or two and some stamp heads, which evidently worked on wooden stems, remain to tell the story. I sampled and assayed some sands which I supposed were tailings of these old works which ran as high as $\$ 79$ gold per ton. These ores probably came from the bonanzas found soon after the first discoveries, a number of the workings of which may yet recognized, though in bad condition. It is conservatively estimated that these properties have produced upwards of $\$ 1,000,000$ American gold.

Among interesting historical facts relative to these mine, I learned that Mr. Richard Trevithick, the immortalized English inventor, who was then in Peru, upon hearing of the rich finds in Costa Rica, came to this district in 1824, and for about two years explored and worked some of the Sacra Familia mines. He became convinced of the opportunities presented there, sailed for England and organized the Anglo-Costa Rica Mining Company, which worked the mines with limited capital and little success, attributed to bad management.

Another interesting work was done by a Cornishman named Phillips and a Costa Rican named Moya, who worked some of these mines form 1837 to 1844 . Phillips is said to have located a very rich bonanza. He concealed the fact and tried to get title to the property, but the owners were made suspicious by his anxiety and refused to accept the propositions he made. He then completely obstructed the tunnel which lead to the deposit, a distance of perhaps 200 feet, filling with the rock he has excavated and caved in the entrance, leaving only such marks as he himself could recognize. He then left the country with the intent, it is thought, of returning with sufficient funds to acquire the mine. Nothing was known of his plans for many years, until some natives who assisted him in the work disclosed the secret. It was not until in November, 1901 that his old working was re-located, and it is now being reopened with much interest.

\section{Los Castros}

The first discoveries and denouncements in this group, which joins the Aguacte properties on the north and east, were made in 1822 by the brothers, Nicholas and Pio Castro. The vein is a continuation and the same as the Oreamunos and San Rafael. The lode displays the characteristics of three sub-veins, called Veta Colorado, Veta Negra and Veta Blanca. Samples taken from cross-cuts of the veins assay from $\$ 28$ to $\$ 45$. Several fortunes are said to have been taken from the surface workings of these mines, known as the bonazas Don Ricardo, El Manto, El Pochote, Don Antonio Pinto, Lacre , Sequiera and Don José Antonio Castro. The last named is said to have produced $\$ 15,000$ in a single day.

\section{El Porvenir}

This mine is situated west of the Aguacate mines, on the Rio Machuca, a short distance north of San Mateo. The property has been sufficiently prospected to prove the existence of some attractive veins. The veins consist of the main ledge, which courses the center the full length of the property at an angle of about $30^{\circ}$ east of north, and several subsidiary veins which unite with it. This mine has been the resource of many native living in that vicinity for many years, who have worked the surface ores with molinettes and arrastras, nothing more modern having been attempted. It is known that they made good wages with the gold pan. One good authority told me of an instance when one ounce and a half of gold was obtained from a hat full of ore found in this mine. A bonanza was found some years ago in a working called Guatuso, from which it is estimated that $\$ 60,000$ was realized by 
amalgamation in an arrastra. Assays I have made of sampled taken in these old workings indicate that considerable rich ore remains yet in place. I made a great many assays from different places about this mine, ranging from $\$ 10$ to $\$ 2,000$ per ton, and believe that after sufficient development is done, an abundant supply of ore, ranging from $\$ 15$ to $\$ 25$ can be obtained. A larger percentage of the values in these ores is free and amalgamatable, and the values remaining I believe can be recovered with cyanide.

The natural conditions at this mine are especially favourable, affording ample power and convenient mill-site near the entrance of the main tunnel, which will begin at the south end of the claim on the main ledge and at a low level. This tunnel with appurtenant upraises and cross-cuts is now contracted, and the ore will be blocked out before a plant for treating the ores is constructed. This mine is the property of the Rio Grande Gold Mining Company.

Quebrada Honde Mine.-This property joins the claims of the Sacra Famila mines on the west, on the Rio Quebrada Honde, and is one of the oldest worked mines in the district. It is said that a great many men were employed here at one time working the ores in a series of arrastras on the river. There has been no production for many years, probably not since 1857 . The property consists of three principal veins and numerous feeder veins. The deepest shaft in this district was sunk on this property and was less than 400 feet deep. Many of the old workings are now inaccessible.

The mine is prettily located and the site, which was one time densely inhabited, is covered with large trees and other rank vegetation. There remains the ruins of molinettes, arrastras and a 10stamp mill of early pattern, the date of operation and production of which I have not learned. The ores treated by these crude methods are said to have yielded immense profits, and best authorities estimate that the mine has produced upwards of $\$ 1,000,000$. So far as a general removal of ore is concerned, the property is practically virgin. The principal veins vary in width form 3 to 20 feet, carrying values averaging $\$ 8$ per ton and upwards.

The production up to date of the mines of the Aguacate District is estimated to exceed $\$ 7,000,000$ gold, and has probably reached the sum of $\$ 10,000,000$. Considering that this sum has been produced by the crudest mining and metallurgical methods, the reward which would follow the proper application of capital, sufficient to operate on a large and modern scale, seems surmisable. All of the known ore bodies are so situated as to permit the development of the three principal groups of the district by one great tunnel with convenient drifts, the course of which could be directed so as to cut the vein at great depth and give backs extending far below the deepest workings so far made, and who can know the new and possibly richer deposits such a work would disclose. The work done has been sufficient to prove the presence of many veins and deposits which warrant mining and treatment if but half of the values are recovered. There is no reason for a belief that these deposits do not continue to great depth, and the deepest workings indicate that they do. The ores become slightly refractory and the values in silver increase with a gold value constant as depth increases. In is believed that proper treatment will result in saving from 85 to 90 per cent of the values in these ores.

\section{MONTE DE ORO DISTRICT}

\section{Trinidad Mine}

This property is owned by an English company, though Mr. Minor C. Keith, an American, is said to hold the majority of stock. The property includes some large veins of low-grade ore, $\$ 6$ to $\$ 10$ per ton. Operations were suspended about 10 years ago, owing to the heavy loss in tailings. Plain amalgamation was used, with the result that two-thirds of the values were lost. No extensive experimental work has been done to properly test the ores, but it is believed that they will cyanide to at least 85 per cent. Some rumors have recently been afloat that $\mathrm{Mr}$ Keith would soon reopen the mine at new and lower levels.

\section{La Union}

This property is owned by the Union Mining Company, of San Francisco. It has in the past been unsuccessfully worked. A 20 stamp mill was 
operated without a profitable recovery. No other treatment than amalgamation has been applied, with a consequent loss, it is states, of about 60 per cent of the values, which averaged from $\$ 5$ to $\$ 8$ per ton. Three years ago a chlorination plant was constructed, but for some unaccountable reason a single charge was never chlorinated. Fifteen months ago a serious cave-in occurred, and for the following ten months the property remained idle. A recent effort to reopen the mine by two lesser seems to have been unsuccessful. At present the former superintendent, Mr. John W. Kerr, is reported to be operating the mill with a view to recovering the free gold from some of the better ore remaining in the stopes.

\section{Macacona Mine}

This mine was worked about 30 years ago by a native company with small capital and inferior appliances. Nevertheless, it is recorded that good dividends were earned. The mine was operated through a shaft, and with depth the difficulty on account of water increased. The mine was closed down for some years. Several years ago the property was acquired by R.A. Crespi \& Co., who have added a hoisting, pumping and drilling plant with a view to the better development of the property. The pay portion of the ledge is narrow but runs, it is stated, about $\$ 90$ per ton. Treated on a large scale the owners believe the entire vein will pay a good profit.

\section{Thayer Mining and Milling Company}

This company owns and operate the mines locally known as the Bella Vista and the Montezuma. They are situated near the village of Miramar, in the District of Puntarenas, about fifteen miles from the Pacific port. These properties have been undergoing active development for the past six years. The ore bodies excavated and exposed during this time indicate an abundance of ore. Ranging in value from $\$ 5$ to $\$ 10$ per ton. The situation here will permit mining large quantities of ore of this class above water level.
The ore is being treated in two 20 stamp mi1ls, where from 45 to 50 per cent of the values are obtained by amalgamation. The tailings from the plates are passed over Wiltley concentrators. The tailings of these and the concentrates are separately treated in cyanide, which with the saving on the plates has a total saving of from 85 to 90 per cent. The present capacity is 100 tons per day. The company contemplates doubling this capacity during this year, which will materially increase the output with but a slight proportionate increase in operating expense. A waterway is being constructed to supply additional power for the enlarged plant, uniting part of the Rio Barranca with the Rio Rhin (Nota: río Ciruelas), which has up to this time furnished all the power used. According to recent reports from these mines there is now sufficient ore blocked out to supply eighty stamps for at least two years.

Statements made by able engineers from the United States who have examined these mines indicate a bright future and warrant more extensive operation. Mr. A.F. Holden, of Cleveland, Ohio, says in his report: "The development on the lower levels of the properly indicates a permanency to the ore chutes and a strength to the veins that promise an attractive future for the whole property. The mining and milling advantages at the Thayer mines are excellent. I believe the cheap labor, the freedom from import duties on all mining materials and the natural advantages of the location should reduce the cost of operation to the minimum."

Mr. Henry C. Holthoff, of Milwaukee, Wiss., who examined the property, and Mr. E.C. Small, of Salt Lake City, a metallurgist of considerable experience, who spent six weeks at the mines, also made favourable reports. The present output of the Thayer company`s mines is from $\$ 8,000$ to $\$ 10,000$ American gold per month.

\section{THE MINES OF THE ABANGAREZ DISTRICT}

This district is situated near the north end of the Gulf of Nicoya. It comprises about 150 sqare miles of mineral property. It is owned chiefly by 
the Abangarez Gold Fields, Limited ; Las Cañas Syndicate ; Guanacaste Syndicate, and R.A. Crespi \& Co.

Abangarez Gold Fields, Limited.-This company owing 30 square mile of this district, has been prospecting and developing for the past four or five years. The country rock is generally porphyritic. The quartz occurs in a mass of porphyry, but it is possible in some instances that the lodes may prove to be contact veins between dike intrusions and the older rocks. Some of the veins belong to the gash type, and the probabilities are that these will feather out at depth ; others, again are of great strength, notably the Tres Hermanos, a powerful vein of from 6 to 20 feet in width, and the Big Gilo, 6 to 12 feet in width. Such lodes may be classed as fissure veins, for their length and strength are such as to warrant the assumption that they penetrate to great depth. The ore of the Tres Hermanos veins assays $\$ 8$ per ton and the Big Gilo \$25 per ton. This information is given on the authority of the Messrs. John Taylor \& Sons, of London, who examined these mines in 1897.

Eleven district veins are now in process of development, and the company is erecting a 40-stamp mill of 900-pound stamps, with a 300 horse-power electrical transmission plant, which will be at work by August of this year. A development mill, which has been in operation for some time, is handling 500 tons per month, worth $\$ 17$ per ton. By amalgamation and cyaniding 90 per cent of the values is being procured. The success upon which this company is apparently just entering is largely due or attributable first, to the ability and persistence bestowed upon the earlier development of the properties by Mr. R.A. Crespi and, second, to the skill of Mr. C.H. Colburn, the present engineer and manager.

\section{Boston Mines Company}

This subsidiary company to the Abangarez Gold Fields, Limited, is operating the Tres Amigos Mine, and is now erecting a 10-stamp heavy battery, with cyanide annex. A 3-stamp prospecting mill has been at work for the past twelve months on this property crushing ore averaging $\$ 30$ per ton and extracting about 60 per cent by amalgamation.

\section{Las Cañas Syndicate}

This corporation owns 27 properties, one of which is a vein known as the Esperanza, which is 70 feet from wall to wall and carries an average of $\$ 10$ per ton. There are several feeders or gash veins running into the main ledge carrying higher values. The ore is suitable for economic milling, and water power is practically unlimited.

\section{Guanacaste Syndicate}

This syndicate owns 30,000 acres of mineral land, which embraces some large ledges that are now being prospected and developed. Among others there are: The Gier vein, 60 feet wide, assaying $\$ 8$ per ton; the Oracu small, $\$ 60$ per ton. The ores are similar to those of the Abangarez Syndicate in character, and it is believed are adaptable to the same treatment, amalgamation and cyaniding. It is understood that this syndicate later proposes to form one or more companies for development and operating purposes. Las Cañas and Guanacaste Syndicate properties are controlled by Messrs. R.A. Crespi \& Co. No machinery has as yet been erected, but these gentlemen have a force of prospectors and surveyors at work.

Since the report of Messrs. Taylor \& Sons was made several large veins have been located and are now being thoroughly prospected. The values held by the main ore fissure ledges seem to be well maintained at depth. In the Abangarez property a vein carrying $\$ 24.72$ per ton in its surface workings is found to carry $\$ 40$ per ton at 300 feet below the surface was recently opened.

\section{CONCLUSION}

The opinion is prevalent here among many of the best business men of the republic that in the business of gold mining Costa Rica is about to put her best foot forward. Among mining men, those best informed believe that within 10 or 15 years the mining business will be the chief industry of the republic. Other industries of the country upon which the mining business somewhat depends are progressing favourably. 
No reference can be made to many other promising mineral properties without lengthening this article beyond reasonable bounds of space.

\section{Nota de transcripción}

El texto original incluye cuatro figuras:

- Mining districts of Costa Rica: un mapa de Costa Rica donde están marcados los tres distritos de oro en forma de bloques.
- Preparing mine timbers in Costa Rica (foto) - Ross placer mine, near San Jose, Costa Rica (foto) - Remains of old arrastra at El Provenir (foto) Sin embargo, como solo se dispone de una fotocopia en papel térmico la calidad de las figuras, especialmente de las fotografías es mala y no permite una reproducción. 